\title{
Yield Performance of Black Gram (Vigna mungo L.) Variety (LBG-20) at Farmers' Field of Mandla District of Madhya Pradesh
}

\author{
H.S. Rai ${ }^{{ }^{*}}$, Sweta Rai ${ }^{2}$ and R.S. Marabi ${ }^{1}$ \\ ${ }^{1}$ Department of Entomology, JNKVV, College of Agriculture, \\ Tikamgarh - 472001 (M.P.), India \\ ${ }^{2}$ Medicinal Pharmaceutical Chemistry, Kashi Institute of Pharmacy, Varanasi (U.P.), India \\ *Corresponding author
}

\section{A B S T R A C T}

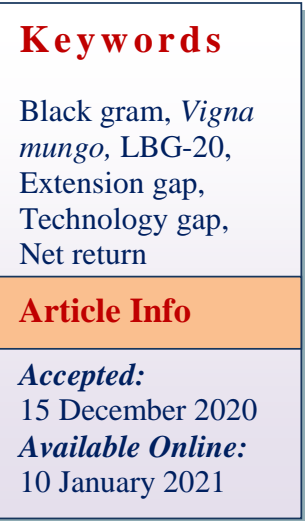

\section{Introduction}

Black gram [Vigna mungo (L.) Hepper] is one of the most important legume crops of India. Being a pulse it has vital role in nutritional security and major sources of vegetable proteins in Indian diet. India is the world's largest producer of pulses imports a large quantity of pulses to meet out the growing domestic needs. It contains about $20 \%$ protein, which is almost three times higher than cereals, other minerals and vitamins. The demand of pulses particularly black gram is supplied across the world due to its higher consumption where animal proteins are insufficient and comparatively expensive (Ofuya and Akhidue, 2005). It is resistant to adverse climatic conditions and improves the 
soil fertility by fixing atmospheric nitrogen in soil and contribute in crop produce equivalent to $22.10 \mathrm{~kg}$ of N/ha. In Madhya Pradesh, the black gram is cultivated in 1788.80 thousand ha area and production of 1744.35 thousand MT with the productivity of $975 \mathrm{~kg} / \mathrm{ha}$ whereas, in Mandla district, it is cultivated in 2 thousand ha area and production of 1.44 thousand MT with the productivity of 718 $\mathrm{kg} / \mathrm{ha}$ (Anonymous, 2019). Since last few years the average production and productivity has declined due to attack of insect pests, diseases and drastically changes of climatic conditions. Soil and climatic conditions play an important role in crop rotation, mixed and inter-cropping, leading soil fertility via nitrogen fixation, release of soil-bound phosphorus ultimately contribute significantly to sustainability of the farming systems. It is therefore, necessary to assess the technological intervention gaps in production and also to know the problems and constraints in adopting improved variety of black gram production technologies (Islam et al., 2011 and Kumar et al., 2014). Availability of quality seed of improved varieties and other inputs is one of the major constraints in increasing the production of legume crops. In this context, Krishi Vigyan Kendra is a grass root level organization meant for catering application of technology through demonstrations (cluster front line demonstration and on farm testing), training schools, yield assessment, refinements and dissemination of proven technologies under different micro farming situation in the district levels (Dubey et al., 2010).

Though, huge numbers of resistant / tolerant varieties of black gram have been developed by researchers but dissemination of such varieties at farmers' field level is experienced very scanty. This is due to the lack of knowledge and awareness in the farmers and gap of new transfer technology, motivational trainings through field demonstrations to build up reliance towards the changing their cropping system. The technology adoption and awareness regarding black gram cultivation, adoption of new practices must be improved to lessen the gaps in the farmer's practices. Certainly, field level demonstrations of new crop varieties is planned to demonstrate their high yield potential at farmers field. Eventually, it will enhance requirement for quality seed of new seed varieties ultimately towards the adaptation and maximization of black gram production. Thus, keeping the above facts in mind the present study was conducted to study the performance of black gram variety at farmer's field level and gap analysis of variety production through on farm testing (OFT) to establish potential production for getting good economic returns.

\section{Materials and Methods}

A field demonstration was conducted to know the performance of black gram variety (LBG20) at farmers' field in Mandla district, Madhya Pradesh consecutively during three kharif seasons 2013, 2014 and 2015. The demonstration trials of black gram were carried out in 4.8 ha area at farmer's field adjacent the farmer's practices. The soil condition of demonstration area was light soil having medium to high fertility status. The demonstration module technology includes improved variety of black gram (LBG-20), seed treatment with Thirum + Bavistin @ $2.5 \mathrm{~g} / \mathrm{kg}$ seed and Trichoderma virdae @ $10 \mathrm{~g} / \mathrm{kg}$ of seed, inoculation of microbial organism Rhizobium + phosphorus solubilizing bacteria (PSB) @ 20 gm/kg seed, weed management (one hand weeding at 2530 DAS $)$, seed rate $(20 \mathrm{~kg} / \mathrm{ha})$ and line sowing method. The spacing between rows and plants was maintained with $30 \times 10 \mathrm{~cm}$ in OFT's (Table 1). In plant protection measures, one spray of Quinalphos 25 EC @ 1.5 liter/ha with 500 liter of water was applied against the incidence of leaf defoliator insect pests and proper agronomical practices were maintain 
under demonstrated plots. The treatments comprised of recommended package of practices viz; integrated nutrient management 20:40:20 NPK kg/ha was given based on soil testing reports. Other hand, the farmer's practices were included with local seed having higher seed rate $(25 \mathrm{~kg} / \mathrm{ha})$, broad casting and one hand weeding at 35-40 DAS. The formers neither adopted any seed treatment method with fungicides and biofertilizers nor applied any fertilizer and plant protection measures. The black gram seed was sown between the periods of $15^{\text {th }}$ July to $20^{\text {th }}$ July. The harvesting of crops was done manually at maturity stage and yield data was obtained from demonstrations and farmer's practices for statistical analysis. The production parameters viz; extension gap, technology gap, technology index, yield index, increase yield (\%), benefit cost ratio between demonstrated and existing farmer's practices was computed as described by Samui et al., (2000).

Extension gap $=$ Demonstrated yield - Yield under existing practice

Technology gap $=$ Potential yield Demonstrated yield

Increase yield $(\%)=$

Demonstration yield - Farmers yield

Potential yield

x 100

Technology index $=$

Technology gap
Potential yield

Yield index $=$

Potential yield - Demonstration yield

Potential yield
Grass return

Benefit cost Ratio $=$

Grass cost

\section{Results and Discussion}

\section{Performance of black gram yield}

The yield performances of economic indicators are presented in Table 2. The data revealed that yield of all demonstrated plots of black gram was found to be higher due to high yielding variety (LBG-20) and recommended practices than that of farmer's practices during three consecutive years in kharif seasons 2013, 2014 and 2015. The average yield of black gram under demonstration was recorded 1187, 1239 and $1268 \mathrm{~kg} / \mathrm{ha}$ during 2013, 2014 and 2015, respectively. Other hand, in farmer's practice plots, the average yield was 682, 643 and 632 $\mathrm{kg} / \mathrm{ha}$ during 2013, 2014 and 2015, respectively which was comparatively very less than demonstrated module. However, the obtained seed yield of demonstration trials was quite low as compared to potential yield of black gram variety (LBG-20) which may be caused due to some unavoidable losses. The present finding is corroborated with the findings of Mahalingam et al., (2018), Dubey et al., (2010) and Poonia and Pithia (2011).

The yield enhancement due to technological intervention was higher which ranged from $74.05 \%$ to $100.63 \%$ over farmer's practices. The cumulative effect of the technological intervention over three years revealed on an average yield of $1231 \mathrm{~kg} / \mathrm{ha}$ which was $89.21 \%$ higher over farmer's practices. The yield attributing characters of the variety like number of pods per plant was higher (57 pods /plant) over FP (38 pods /plant). The similar findings were accordance with the findings of Dubey et al., (2010), as they also reported that depending on demonstration, use of farming situation and specific intervention may have 
greater impact in enhancing productivity. Yield enhancement in different crops in OFT's has also been documented by Tomar $e t$ al., (2003).

\section{Extension gap}

The results revealed that extension gap was 505,596 and $636 \mathrm{~kg} / \mathrm{ha}$ recorded during the year 2013, 2014 and 2015, respectively between demonstrations of on farm testing (OFT) and existing farmer's practices (Table 2). The average extension gap was recorded
$579 \mathrm{~kg} / \mathrm{ha}$ between demonstrations of on farm testing (OFT) and farmer's practices. Present findings are the conformity with the findings of Dhaka et al., (2010), Bairwa et al., (2013) Kothyari et al., (2018) and Mahalingam et al., (2018). Apparently, the extension gap is considered as main constraint which should be minimized by adopting some new technological interventions through demonstrations at farmer's field to change their mind set towards the acceptance of high yielding crop varieties and innovative agricultural technologies.

Table.1 Gap analysis between demonstration practices and farmer's practices

\begin{tabular}{|c|c|c|c|c|}
\hline S. No. & Practices & Demonstration practice & Farmer's practice & Gap \\
\hline 1. & Land preparation & Two ploughing & Two ploughing & No gap \\
\hline 2. & Variety & LBG-20 & Local seed & Full gap \\
\hline 3. & Seed rate $(\mathrm{kg} / \mathrm{ha})$ & $20 \mathrm{~kg} / \mathrm{ha}$ & $25-30 \mathrm{~kg} / \mathrm{ha}$ & Higher seed rate \\
\hline 4. & Seed treatment & $\begin{array}{l}\text { Thirum+Bavistin 2:1 @ } \\
2.5 \mathrm{~g} / \mathrm{kg} \text { seed and } \\
\text { Trichoderma virdae } \\
\text { @ } 10 \mathrm{~g} / \mathrm{kg} \text { of seed }\end{array}$ & No seed treatment & Full gap \\
\hline 5. & $\begin{array}{l}\text { Sowing method } \\
\text { and spacing }\end{array}$ & Line sowing $(30 \times 10 \mathrm{~cm})$ & $\begin{array}{l}\text { No line sowing } \\
\text { (Broad casting) }\end{array}$ & Full gap \\
\hline 6. & \begin{tabular}{|l} 
Manures and \\
Fertilizers
\end{tabular} & $20: 40: 20$ NPK kg/ha & $\begin{array}{l}\text { No use of fertilizer } \\
\text { (Negligible) }\end{array}$ & Full gap \\
\hline 7. & Weed management & $\begin{array}{l}\text { One hand weeding at } 25- \\
30 \text { DAS }\end{array}$ & $\begin{array}{l}\text { One hand weeding } \\
\text { at } 35-40 \mathrm{DAS}\end{array}$ & Partial gap \\
\hline 8. & $\begin{array}{l}\text { Plant protection } \\
\text { measure }\end{array}$ & $\begin{array}{l}\text { Need based plant } \\
\text { protection measures }\end{array}$ & $\begin{array}{l}\text { No plant protection } \\
\text { measures }\end{array}$ & Full gap \\
\hline
\end{tabular}


Table.2 Productivity, extension gap, technology gap and technology index of black gram as grown under OFT'S and existing farmer's practices

\begin{tabular}{|c|c|c|c|c|c|c|c|c|c|c|}
\hline \multirow[t]{2}{*}{ Year } & \multirow{2}{*}{$\begin{array}{l}\text { Area } \\
\text { (ha) }\end{array}$} & \multirow{2}{*}{$\begin{array}{l}\text { No. of } \\
\text { OFT's }\end{array}$} & \multirow[t]{2}{*}{ Variety } & \multicolumn{3}{|c|}{ Average yield ( kg/ha) } & \multirow{2}{*}{$\begin{array}{l}\text { Increase } \\
\text { yield over } \\
\text { F.P. }(\%)\end{array}$} & \multirow{2}{*}{$\begin{array}{c}\text { Extension } \\
\text { gap } \\
(\mathbf{k g} / \mathbf{h a})\end{array}$} & \multirow{2}{*}{$\begin{array}{l}\text { Tech. } \\
\text { gap } \\
\text { (kg/ha) }\end{array}$} & \multirow{2}{*}{$\begin{array}{l}\text { Tech. } \\
\text { Index } \\
(\%)\end{array}$} \\
\hline & & & & Potential & Demo. & Farmers & & & & \\
\hline 2013-14 & 4.8 & 12 & LBG-20 & 1400 & 1187 & 682 & 74.05 & 505 & 213 & 1.52 \\
\hline 2014-15 & 4.8 & 12 & LBG-20 & 1400 & 1239 & 643 & 92.69 & 596 & 161 & 1.15 \\
\hline 2015-16 & 4.8 & 12 & LBG-20 & 1400 & 1268 & 632 & 100.63 & 636 & 132 & 0.94 \\
\hline Total & 14.4 & 36 & - & - & 3694 & 1957 & 267.37 & 1737 & 506 & 3.61 \\
\hline Mean & 4.8 & 12 & - & - & 1231 & 652 & 89.12 & 579 & 168 & 1.20 \\
\hline
\end{tabular}

Table.3 Profitability of balck gram grown under on farm testing (OFT's) and existing farmer's practices

\begin{tabular}{|c|c|c|c|c|c|c|c|c|}
\hline \multirow[t]{2}{*}{ Year } & \multicolumn{2}{|c|}{$\begin{array}{l}\text { Average cost of cultivation } \\
\text { (Rs./ha) }\end{array}$} & \multicolumn{2}{|c|}{$\begin{array}{c}\text { Average gross return } \\
\text { (Rs./ha) }\end{array}$} & \multicolumn{2}{|c|}{$\begin{array}{c}\text { Average net return } \\
\text { (Rs./ha) }\end{array}$} & \multicolumn{2}{|c|}{ B:C Ratio } \\
\hline & OFT's & $\begin{array}{l}\text { Farmers } \\
\text { practice }\end{array}$ & OFT's & $\begin{array}{l}\text { Farmers } \\
\text { practice }\end{array}$ & OFT's & $\begin{array}{l}\text { Farmers } \\
\text { practice }\end{array}$ & OFT's & $\begin{array}{l}\text { Farmers } \\
\text { practice }\end{array}$ \\
\hline 2013-14 & 16348 & 13360 & 47480 & 27280 & 31132 & 13920 & 2.90 & 2.04 \\
\hline 2014-15 & 16680 & 13480 & 49560 & 25720 & 32880 & 12240 & 2.97 & 1.90 \\
\hline 2015-16 & 16730 & 13759 & 50720 & 25280 & 33990 & 11521 & 3.03 & 1.84 \\
\hline Total & 49758 & 40599 & 147760 & 78280 & 98002 & 37681 & 8.90 & 5.78 \\
\hline Average & 16586 & 13533 & 49253 & 26093 & 32667 & 12560 & 2.97 & 1.93 \\
\hline
\end{tabular}




\section{Yield gap and technology index}

The yield gap in the demonstration of black gram (LBG-20) yield over farmer's yield was recorded maximum during the year 2015 (636 $\mathrm{kg} / \mathrm{ha}$ ) followed $2014(596 \mathrm{~kg} / \mathrm{ha})$ and 2013 (505 kg/ha) (Table 2). The observed technological gap may be attributed dissimilarity in soil status, rainfall distribution, infestation of insect pests and disease as well as the change in the locations of demonstrated plots in every year. The technology gap in the black gram (LBG-20) demonstration yield over potential yield was recorded maximum $(213 \mathrm{~kg} / \mathrm{ha})$ during kharif 2013, followed by $2014(161 \mathrm{~kg} / \mathrm{ha})$ and 2015 $(132 \mathrm{~kg} / \mathrm{ha})$. Further, it is revealed that the technology index 1.52, 1.15 and 0.94 percent was found during the year of 2013, 2014 and 2015 , respectively. The lower value of technology index expressed about the more plausible feasibility of the black gram variety (LBG-20) at the farmer's field. The results revealed that the extension and technology gaps are existed between transfer technology and technology adoption at existing farmer's field. The present findings are in accordance with the findings of Thakral and Bhatnagar (2002), Dhaka et al., (2010), Bairwa et al., (2013), Kumar et al., (2014) and Ganga Devi et al., (2017).

\section{Evaluation of economic return}

The economic indicators in term of cost of cultivation, gross returns, net returns and benefit cost ratio of demonstration and existing farmer's practices is given in Table 3 . The data clearly depicted that the net return from the recommended practices was substantially higher than farmer's practices. The average cost of cultivation from recommended practice was found to be Rs. $16586 /$ ha as compared to farmers practices i.e. Rs.13533/ha. Although, the cost of cultivation of OFT's was higher than that of farmer's practices but the average net return was obtained higher due to undertaken all recommended practices. On an average Rs. 20107/ha as additional income is attributed to the technological intervention provided in demonstrated module i.e. recommended package practices. Average net returns from recommended practices was found to be Rs. $32667 /$ ha as compared to farmer's practices i.e. Rs.12560/ha. The average B:C ratio 2.97 was found under OFT's whereas, 1.93 in farmer's practices. The similar findings were also obtained by Bairwa et al., (2013), Ganga Devi et al., (2017) and Jain et al., (2020). The present study is concluded that the yield response and economic returns of improved variety of black gram (LBG-20) was found to be higher than farmer's practices due to following the recommended package of practices.

\section{References}

Anonymous. 2019. http://mpkrishi.mp.gov.in/hindisite_Ne w/APY\%202016-17_to_201819.pdf

Bairwa, R. K., S. R. Verma, K. Chayal and N. L. Meena. 2013. Popularization of Improved Black gram Production Technology through Front line demonstration in humid southern plain of Rajasthan. Indian Journal of Extension Education and R.D. 21: 97101.

Dhaka, B.L, B.S. Meena and Suwalka, R. L. 2010. Popularization of improved maize technology through Frontline Demonstration in South-eastern Rajasthan, Journal of Agricultural Sciences. (1): 39-42.

Dubey S, S. Tripathi, P. Singh and Sharma, R.K. 2010. Yield gap analysis of black gram production through frontline demonstration. Journal of Progressive Agriculture. 1(1): 42- 44.

Ganga Devi, M., C.H. Anil Kumar and Srinivas Kumar, D. 2017. Impact 
analysis of trainings and front line demonstrations in black gram (Vigna mungo) cultivation. Journal of Krishi Vigyan. 6(1): 97-100.

Islam M, A. K. Mohanty and Kumar, S. 2011. Correlation growth yield and adoption of urdbean technologies. Indian Research Journal of Extension Education. 11 (2): 20-24.

Jain, D.K., B. Singh and Kumar, H. 2020. Evaluation of cluster front line demonstration on black gram in Udaipur district of southern Rajasthan, India. Journal of Pharmacognosy and Phytochemistry. 9(3): 2209-2212

Kothyari, H. Singh, K.C. Meena, B.L. Meena, Aseray, R. 2018. Evaluation of Cluster Front Line Demonstration on Black gram in Sawai Madhopur District of Rajasthan, India. International Journal of Current Microbiology and Applied Science. 7(1):1569- 1573.

Kumar S., R. Singh and Singh, A. 2014. Assessment of gaps in pulse production in Hamipur district of Himachal Pradesh. Indian Research Journal of Extension Education. 14 (2): 20-24.

Mahalingam, A., V.K. Satya, N. Manivannan, S. Lakshmi Narayanan and Sathya, P. 2018. Inheritance of Mungbean Yellow
Mosaic Virus Disease Resistance in Greengram [Vigna radiata (L.) Wilczek]. Int. J. Curr. Microbiol. App. Sci. 7(01): 880-885.

Ofuya, Z.M. and Akhidue, V. 2005. The role of pulses in human nutrition: A review. Journal of Applied Sciences and Environment Management. 9: 99-104.

Poonia, T.C. and Pithia M.S. 2011. Impact of front line demonstrations of chickpea in Gujarat. Legume Research. 34(4): 304307.

Samui, S.K., S. Maitra, D. K. Roy, A.K. Mondal and Saha, D. 2000. Evaluation of front line demonstration on groundnut (Arachis hypogea L.) in Sundarbans. Journal of Indian Society of Coastal Agriculture Resources. 18(2): 180-183.

Thakral, S. K. and Bhatnagar, P. 2002. Evaluation of frontline demonstrations on Chickpea in north-western region of Haryana. Agricultural Science Digest. 22 (3): 217- 218.

Tomar, L.S., P.B. Sharma and K. Joshi. 2003. Impact of Front Line Demonstrations of soybean in transfer of improved technology. Maharashtra Journal of Extension Education, 22(1): 139.

\section{How to cite this article:}

Rai, H.S., Sweta Rai and Marabi, R.S. 2021. Yield Performance of Black Gram (Vigna mungo L.) Variety (LBG-20) at Farmers' Field of Mandla District of Madhya Pradesh. Int.J.Curr.Microbiol.App.Sci. 10(01): 2294-2300. doi: https://doi.org/10.20546/ijcmas.2021.1001.265 